\title{
Composition of Island-Arc Mantle and its Bearing on the Origin of Cratonic Lithosphere
}

\author{
Pavel Kepezhinskas ${ }^{1}$, Marc J.Defant ${ }^{1}$, Rene Maury ${ }^{2}$, Alan Clague ${ }^{1}$, Jean-Lois Joron ${ }^{3}$ and Jo Cotten ${ }^{2}$ \\ 1. Department of Geology, University of South Florida, Tampa 33620, Florida, USA \\ 2. Dep. Sciences de la Terre et URA 1278, Universite Bretagne Occidentale, 6 Av. le Gorgeu, Brest, France \\ 3. Laboratoire Pierre Sue, CEN Saclay, 91191, France
}

Chemical and mineralogical similarity between island-arc mantle (IAM) peridotites from Kamchatka and Philippines and cratonic harzburgite xenoliths indicates a potential genetic relationship. Arc peridotites have low modal clinopyroxene content and refractory olivine, orthopyroxene and spinel compositions (olivine $\left(\mathrm{Fo}_{91-93}\right)$, spinel $-\mathrm{Cr} /(\mathrm{Cr}+\mathrm{Al})$ of 0.65 to 0.81 , and $\mathrm{Al}_{2} \mathrm{O}_{3}$ in opx - 0.4-1.6 wt. \%) (Figure 1). The modal opx content ranges from 10 to

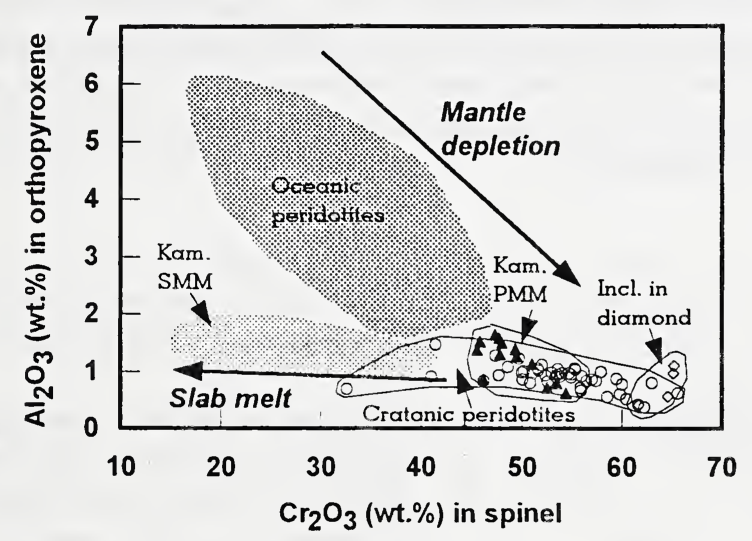

Figure 1. $\mathrm{Al}_{2} \mathrm{O}_{3}$ in orthopyroxene vs. $\mathrm{Cr}_{2} \mathrm{O}_{3}$ in co-existing spinel for Kamchatka pre-metasomatized mantle (Kam. PMM) and slab meltmetasomatized peridotites and pyroxenites (Kam. SMM) compared with oceanic peridotites (Bonatti and Michael, 1989), inclusions in diamond (Gurney and Zweistra, 1995), and cratonic peridotites (Rudnick et al., 1994).

$25 \%$. Arc harzburgites exhibit extremely low $\mathrm{TiO}_{2}\left(0.01-0.03\right.$ wt. \%) and $\mathrm{Al}_{2} \mathrm{O}_{3}$ (0.4-0.6 wt.\%) and high $\mathrm{Cr}$ (2635-4360 ppm), Ni (2361-2600 ppm) and refractory PGEs (Os- 3-6 ppb, Ir- 3.4-6.8 ppb, Ru- 10-28 ppb). IAM is systematically depleted in LILE ( $\mathrm{Ba}$ and $\mathrm{Sr}$ ), HFSE (Ta, Hf, Ti), Th, U, REE compared to primitive mantle and continental lithospheric mantle (CLM) (Figure 2). Enrichments in $\mathrm{Ba}$ and $\mathrm{U}$ relative to other incompatible elements reflect fluid addition from the subducted slab. IAM exhibits a flat chondrite-normalized PGE pattern, virtually similar to cratonic garnet peridotites with an exception of Pt and Au enrichments in IAM peridotites. Cratonic peridotites have other notable similarities to the Kamchatka peridotites: low Al content of co-existing orthopyroxene and spinel, high olivine Fo content, high modal orthopyroxene abundance. Both Kaapvaal and Kamchatka peridotites contain orthopyroxene-rich veins interpreted as a result of slab melt-mantle interaction. A three-stage melt extraction model is proposed to achieve the IAM composition: 1) extraction of MORB melt at mid-ocean ridge; 2) extraction of basaltic melt in back-arc spreading center and 3) hydrous partial melting in a sub-arc mantle wedge to produce arc magmas. This multiple melt extraction produces progressively more extreme depletion in residual mantle. This process may have been 


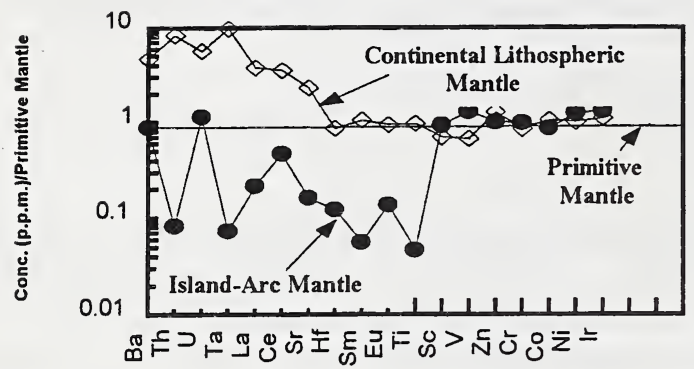

Figure 2. Chondrite-normalized trace element diagram for Island-Arc Mantle (this study) and Continental Lithospheric Mantle (McDonough, 1990).

responsible for growth of continental lithosphere in Precambrian via lateral and vertical accretion as indicated by an apparent synchronicity in TTG crustal production (3.5-2.1 Ga), diamond growth (3.4$1.9 \mathrm{Ga}$ ), Os model ages for cratonic lithospheric peridotites $(3.5-2.7 \mathrm{Ga})$ and kimberlite-borne eclogites (3.4-2.6 Ga) (Pearson et al., 1995). Thicker continental roots below Archean cratons in comparison with rather thin lithosphere of Cenozoic arcs reflect different time scales for lithospheric accretion and growth (e.g. $1000 \mathrm{Ma}$ for cratons and $100 \mathrm{Ma}$ for modern arcs).

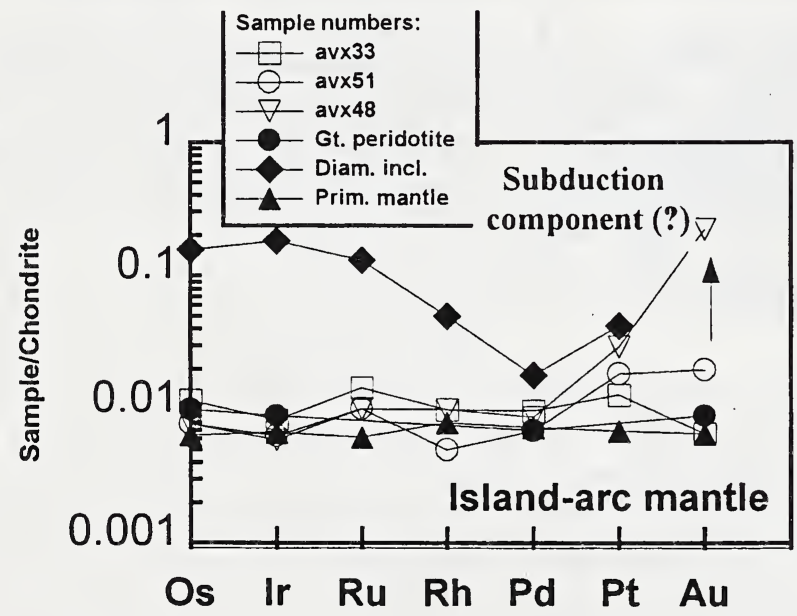

Figure 3. Chondrite-normalized PGE abundance patterns (normalizing values from Naldrett and Duke, 1980) for island-arc mantle xenoliths from Kamchatka (avx33, avx51 and avx48), garnet peridotite (Morgan et al., 1981), primitive mantle (Morgan et al., 1981) and diamond inclusions (Bulanova et al., 1996).

The Pt and Au enrichments observed in IAM peridotites (Figure 3) can be potentially linked to PGE mineralization associated with collision-related Proterozoic gabbro-anorthosite complexes (anorthosite complexes along the southeast margin of Siberian craton, Svekofennian intrusions within the Baltic Shield) and to epithermal gold mineralization in modern arcs and ancient calc-alkaline and TTG igneous suites within Archean cratons. 


\section{References}

Bonatti, E., and Michael, P.J., 1989, Mantle peridotites from continental rifts to oceanic basins to subduction zones: Earth and Planetary Science Letters, v. 91, 297-311.

Bulanova, G.P., Griffin, W.L., Ryan, C.G., Shestakova, O.Ye., and Barnes, S.-J., 1996, Trace elements in sulfide inclusions from Yakutian diamonds: Contributions to Mineralogy and Petrology, v.124, p. 111-125.

Gurney, J.J., and Zweistra, P., 1995, The interpretation of the major element compositions of mantle minerals in diamond exploration: Journal of Geochemical Exploration, v. 53, p. 293-309.

McDonough, W.F., 1990, Constraints on the composition of the continental lithospheric mantle: Earth Planetary Science Letters, v. 101, p. 1-18.

Morgan, J.W., Wandless, G.A., Petrie, R.K., and Irving, A.J., 1981, Composition of the upper mantle, 1. Siderophile trace elements in ultramafic nodules: Tectonophysics, v.75, p. 47-67.

Naldrett, A.J., and Duke, J.M., 1980, Platinum metals in magmatic sulfide ores: Science, v.208, p. 1417-1424.

Pearson, D.G., Carlson, R.W., Shirey, S.B., Boyd, F.R., and Nixon, P.H., 1995, Stabilization of Archean lithospheric mantle: a Re-Os isotope study of peridotite xenoliths from the Kaapvaal craton: Earth and Planetary Science Letters, v.134, p. 341-357.

Rudnick, R.L., McDonough, W.F., and Orpin, A., 1994, Northern Tanzanian peridotite xenoliths: A comparison with Kaapvaal peridotites and inferences on metasomatic reactions: in Meyer, H.O.A., and Leonardos, O., eds., Proceedings of the 5th International Kimberlite Conference, CPRM, Brasilia. 